\title{
Viticulture in Bulgaria - condition and prospects
}

\author{
Kiril Popov ${ }^{1}$, Slavcho Pandeliev², Ludmil Angelov ${ }^{2}$, and Marko Mihaylov ${ }^{1}$ \\ ${ }^{1}$ University of Forestry, 10 Kliment Ohridski Blvd, 1797 Sofia, Bulgaria \\ ${ }^{2}$ Agrarian University, 12 Mendeleev Blvd, 4000 Plovdiv, Bulgaria
}

\begin{abstract}
As industrial culture the vine is grown successfully between $25-50^{\circ} \mathrm{N}$ and $30-50^{\circ} \mathrm{S}$. with certain deviations depending on the orographic features of the terrain. Most suitable conditions for the development of the vine there are in moderately warm regions, located between $34-45^{\circ}$ north latitude. Precisely in this most favorable for development of vine culture zone is located the territory of the Republic of Bulgaria between $41^{\circ} 14^{\prime}$ and $44^{\circ} 12^{\prime} \mathrm{N} /$ Fig. $1 /$.
\end{abstract}

The wonderful soils and climatic conditions for growth and development of the vine and accumulated in Antiquity and the Middle Ages production experience, handed down from generation to generation, were being important prerequisite for the development of viticulture in our lands.

Depending on the climatic diversity in different parts of the country in 1960 are divided and legalized 4 viticultural areas: north, south, east and southwest [5] / Fig. 2 /.

North vine region. The climate in this region is typical continental - with cold winter and hot summer. The amount of active temperature for the area bordering the Danube part are from 3800 to $3980{ }^{\circ} \mathrm{C}$, and for foothill from 3600 to $3760{ }^{\circ} \mathrm{C}$. The average monthly temperature in July is between 22.4 and $24.2{ }^{\circ} \mathrm{C}$, and the average of the absolute minimum temperatures is from -18 to $-20^{\circ} \mathrm{C}$. The length of growing season ranges from 180 to 210 days. The annual rainfall is between 532 and $600 \mathrm{~mm}$ for the area bordering the Danubian part and between 680 and $850 \mathrm{~mm}$ in the foothills.

The soils in the northern region are deep and with good nutrient and mode air. In the streak along Danube they are represented by carbonate and typical, often times eroded chernozems, in the middle - mostly leached and degraded chernozems, and in the foothills meets mostly gray and dark gray forest soils.

Natural conditions in the Northern region are favorable for the production of table and wine grapes for table and quality red wines. Area-specific varieties are Gamza and Vratsa Muscat.

East vine region. The amount of active temperatures fluctuated from 3500 to $3700{ }^{\circ} \mathrm{C}$ for the northern part and from 3700 to $4000{ }^{\circ} \mathrm{C}$ for the southern part. The length of growing season varies between 180 and 240 days. For the region are not typical very low temperatures the average of the absolute annual minimum varies from $-12{ }^{\circ} \mathrm{C}$ for the seaside streak to $-16^{\circ} \mathrm{C}$ inside. The average monthly temperature in July is between 21.8 and $23.5^{\circ} \mathrm{C}$. The annual rainfall is between 470 (Pomorie) and 630 (Shumen) $\mathrm{mm}$. High atmospheric humidity in the coastal area largely offset the deficit of soil moisture.
Soils are deep, well humid and with suitable food regime. They are presented all subtypes of chernozemic and eroded cinnamon forest soils. In the regions of Burgas and Pomorie meet vertisols and in region Varna - gray forest soils overlapped with sea sands.

The area is suitable for cultivation of dessert and wine for the table and quality red and white wines and wine materials for naturally sparkling wines, spirits and aperitifs. Area-specific varieties are Dimiat, Ugni Blanc and Muscat red.

South vine region. The amount of active temperatures from 3500 to $3700{ }^{\circ} \mathrm{C}$ for the first subregion and from 3700 to $4000{ }^{\circ} \mathrm{C}$ for the second. The average of the absolute annual minimum temperatures are of -14 to $-16^{\circ} \mathrm{C}$, but in lowland fluctuated around $-18^{\circ} \mathrm{C}$ and here there is a danger of frost on the vines. The average monthly temperature in July is between 22.6 and $24.5^{\circ} \mathrm{C}$. The length of the vegetation period ranges from 180 to 200 days. The annual rainfalls fluctuates from 650 to $560 \mathrm{~mm}$. The soils are represented by the diversity of cinnamon forest soils near Chirpan meet humus-carbonate, and in the Rhodope collar - and talus soils. In most places they are enough deep with good water, air and diet rejime. In the higher parts of Srednogorie and Rhodope depth of root dwell soil layer is insufficient.

In the area are cultivated vinous varieties for red and white table quality wines. Area-specific varieties are Mavrud, Muscat and red Pamid.

Southwest vine region. By territory is the smallest - It covers the hills along the Struma and Mesta. In the climatic attitude differs sharply from other parts of the country. It belongs in the zone of transient continental Mediterranean climate. Low temperatures below $-16{ }^{\circ} \mathrm{C}$ happens rarely and for a short time. The amount of active temperatures is above $4000{ }^{\circ} \mathrm{C}$. The average monthly temperature for July is 23.5 to $25.1{ }^{\circ} \mathrm{C}$. The length of the vegetation period ranges from 180 to 220 days or more. The annual amount of rainfalls is small $(550 \mathrm{~mm})$ with a pronounced maximum in autumn-winter period.

The terrain of the area is hilly and the vineyards are planted exclusively only on slopes. The soils are mainly 


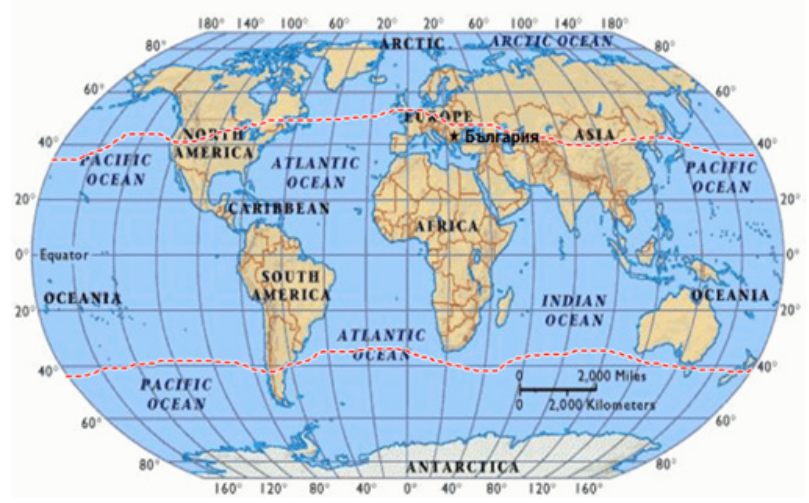

Figure 1. Location of Bulgaria in the area of distribution of vine culture in the world [1].

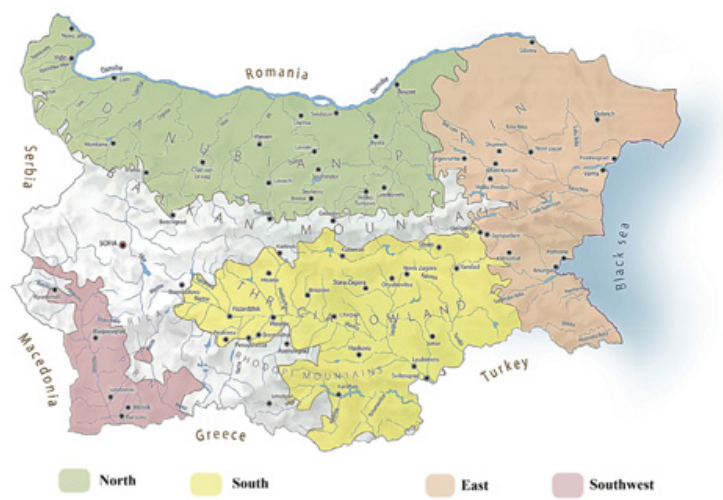

Figure 2. Wine-growing regions in Bulgaria [3].

cinnamon forest, middle to strongly leached In many places, shallow.

The area is suitable for growing a table and vinous varieties for red wines for producing table and quality red dry and table wines. Specific varieties for area are Shiroka melnishka loza and elniê 55.

Depending mainly of the total temperature each of the four areas is divided into three sub-regions with relevant soil and climatic characteristics and varietal composition.

The first subregion covers the hottest places in the country with total temperature sum during the vegetation period of 3700 to $4000{ }^{\circ} \mathrm{C}$. The second subregion with a total temperature sum from 3500 to $3700{ }^{\circ} \mathrm{C}$ covers the hilly and partly semi hilly places of the four described areas.

The third sub-region with a total temperature sum from 3100 to $3500{ }^{\circ} \mathrm{C}$ covers semi mountains places in the vinegrowing areas.

Natural conditions in Bulgaria are suitable as for growing wine varieties / with predominance of red /, and for and the varieties for fresh consumption with different time of ripening grapes. the varietal composition is diverse and includes both local, and introduced varieties vines. Prevailing by acreage from local wine varieties are: Pamid/ 10\% / Muscat red / 7\% / Dimiat / 5\% / Mavrud / $2 \%$ / Melnik / $2 \%$ / Gamza / 1\% /, of the introduced - Merlot / 11\% / Cabernet Sauvignon / 10\% / Rkatziteli / 9\% / Muscat Ottonel / 7\% / Sauvignon Blanc / 2\% /, Syrah / 2\% / Ugni Blanc / 1\% /.

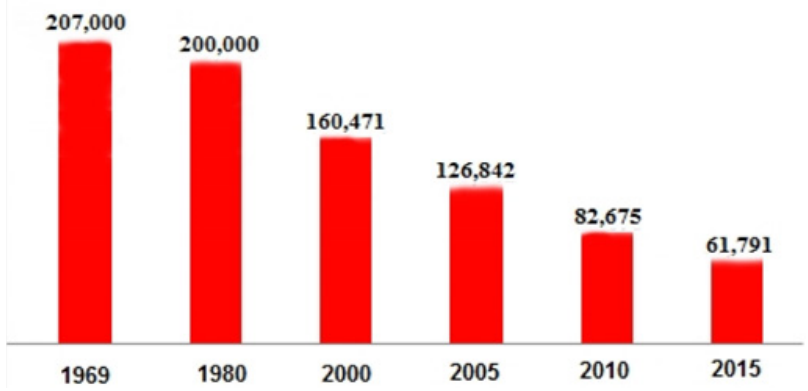

Figure 3. Amendment of areas under vines (ha).

Table 1. Area on harvested vines bystatistical areas and species in 2015.

\begin{tabular}{|l|c|c|c|c|c|}
\hline \multirow{2}{*}{$\begin{array}{c}\text { Statistical } \\
\text { zones }\end{array}$} & \multicolumn{3}{|c|}{ Wine varieties } & $\begin{array}{c}\text { Table } \\
\text { variety }\end{array}$ & Total \\
\cline { 2 - 5 } & Red & White & Total & \\
\hline $\begin{array}{l}\text { North and } \\
\text { Southeast } \\
\text { Bulgaria }\end{array}$ & 11319 & 10058 & 21377 & 1004 & 22381 \\
\hline $\begin{array}{l}\text { Southwest } \\
\text { and South } \\
\text { Central } \\
\text { Bulgaria }\end{array}$ & 12718 & 2363 & 15081 & 1250 & 16331 \\
\hline Total area & 24037 & 12421 & 36458 & 2254 & 38712 \\
\hline
\end{tabular}

In our country have been proven two technologies of growing vines - low ground and stem / medium and high stem /. low ground fledge is imposed only in areas where absolute minimum temperatures fall at least once every 10 years under $-15,-18^{\circ} \mathrm{C}$. These technologies are applied to small areas in the personal farm and collections. Stem formations are with height of the stems of the vines up to 100 and over $100 \mathrm{~cm}$ with unilateral or bilateral branches and with formed on their short or mixed fruit units. Planting distances are depending on the biological characteristics of the variety, shape and the soil. Prevailing are the distances from 2 to $2.50 \mathrm{~m}$ between the lines and from $1-1.20 \mathrm{~m}$ inside the lines vinous and from 1.20 to $1.50 \mathrm{~m}$ for table wines. The retaining structures are built from wooden, metal or ferroconcrete pillar.

By area of vineyards Bulgaria has been always between the top 10 countries in the world. In 1969 the area of vineyards in the country amounted to 207 thousand ha, by which 149 thousand ha are occupied by wine varieties and 51,7 thousand ha with table wines /Fig. 3/.

In subsequent years, the area of vineyards gradually decreases, as in last 15 years these changes are essential. As a result, and occurred socio-economic changes in the country, the area of vineyards decreased with $62 \%$.

One of the reason for keeping a relatively high production of grapes till 2000 is good preserved juridical status of holdings. In the four areas, physical persons grown about $76 \%$ of the vineyards, and the agricultural cooperatives around $20 \%$. Other manufacturers grows $4 \%$ of vineyards.

The harvested area of vineyards by species to 2015./ Table $1 /$ indicates that the structure is good. The greatest area is with red, followed by white wine varieties and at least table varieties. 


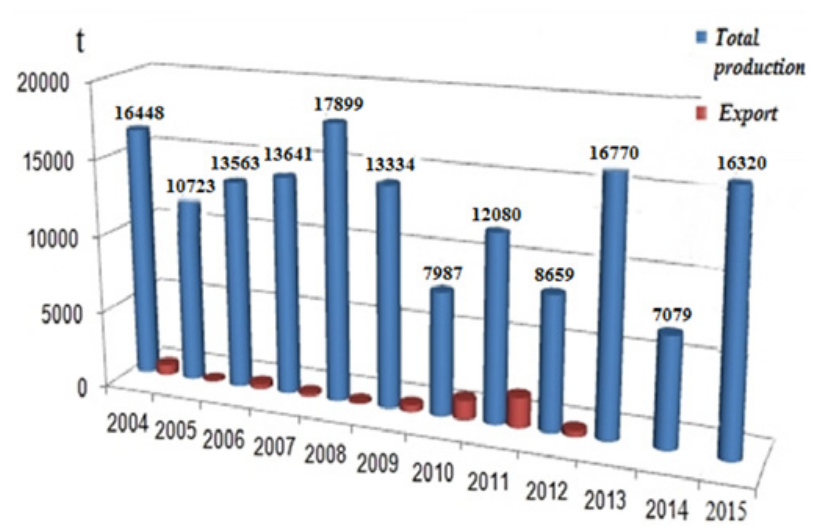

Figure 4. Dynamics of production and export of table grapes for the period 2004-2015.

Table 2. Production of grapes in Bulgaria by statistical areas and species in $2015, \mathrm{t}$.

\begin{tabular}{|c|c|c|c|c|c|}
\hline \multirow{2}{*}{$\begin{array}{l}\text { Statisticall } \\
\text { zones }\end{array}$} & \multicolumn{3}{|c|}{ Grapes from vineyards, $t$} & \multirow{2}{*}{$\begin{array}{l}\text { Grapes } \\
\text { from } \\
\text { liana } \\
\text { vines } \\
t\end{array}$} & \multirow{2}{*}{$\begin{array}{c}\text { Total } \\
\text { produced } \\
\text { grapes } \\
\text { t }\end{array}$} \\
\hline & Vinous & $\begin{array}{l}\text { Table } \\
\text { vines }\end{array}$ & Total & & \\
\hline $\begin{array}{l}\text { North and } \\
\text { Southeast } \\
\text { Bulgaria }\end{array}$ & 156327 & 8163 & 164490 & - & - \\
\hline $\begin{array}{l}\text { Southwest } \\
\text { and South } \\
\text { Central } \\
\text { Bulgaria }\end{array}$ & 88030 & 8157 & 96187 & - & - \\
\hline $\begin{array}{l}\text { Total for } \\
\text { Bulgaria }\end{array}$ & 244357 & 16320 & 260677 & 1143 & 261820 \\
\hline
\end{tabular}

The average yield of grapes for the country of wine varieties is $6702 \mathrm{Kg} / \mathrm{ha}$, and for table variety $7240 \mathrm{sc} \mathrm{kg} / \mathrm{ha}$.

The total production of grapes in 2015 amounted to 261820 tons /Table 2/. [4]

From 261,820 tons produced grape, 242,936 tons is processed, as 195,860 tons is vinified in wineries, and 42176 tons outside them and 4900 tons is processed in other products.

Processing of grapes is concentrated in more than 250 wineries in Bulgaria [4].

The table grape production in the country till 1980 is relatively well developed. The first export of table grapes was made in 1926 from 155 tons. Twelve years later /1938./, Bulgaria exports 12000 tons mainly variety Bolgar and ranks first in the world in the export of table grapes. In 1965 Bulgaria is again first by exporting grapes in the world. Today, Bulgaria almost not export table grapes /Fig. 4/ [4].

Sharp decline in the consumption of table grapes in the country from $25-30 \mathrm{~kg}$ in 1960 . on $2-3 \mathrm{~kg}$ per capita in 2016. Average yields from table grapes vary from 2640 to $7305 \mathrm{~kg} / \mathrm{ha}$ for the period $2000-2015$ [6].

The reasons for reduced production of table grapes in the country are a few:

1.1 Accelerated abandon and poor maintenance of the table vineyards.
1.2 Giving the vineyards for temporary use by different farmers.

1.3 Breaking the retaining construction of a large part of the plantations.

1.4 Losses of markets led to a deterioration of economic efficiency on vineyard and accelerating the eradication of most of them.

1.5 Improper and ineffective land reform.

1.6 Insufficient manpower and low qualification.

1.7 Impaired link between science and production.

1.8 Insufficient using of available resources for various programs.

The controls in the sector is regulated by law wine and spirit drinks(decree N0283/16.09.1999.), with which are created two structures:

1. Executive Agency on Vine and Wine (EAVW). It is a state body supervising the observance of the law on wine and spirits onto vineyard plantations, grapes intended for wine making, grape musts, products of grapes and wines. EAVW is a legal entity with headquarters city Sofia and 9 territorial links in Montana, Pleven, Ruse, Varna, Burgas, Sliven, Haskovo, Plovdiv and Blagoevgrad;

2. National Vine and Wine Chamber (NVWC). It is a professional branch organization, which supports,controls and protects the interests of its members. NVWC is legal entity with headquarters city Sofia and carries out its activities through 5 regional vine-wines chambers with headquarters in Pleven, Varna, Haskovo (since 2001 Moved in Sliven), Plovdiv and Blagoevgrad. In July 2006 launched a reform of the vine-wine sector in the EU to prioritize the following prospects:

- Expanding markets;

- Increasing competition in the European winemaking;

- Saving the best traditions of Europe in the area of winemaking.

Are recommended the following measures in national envelopes:

- Popularization of wine in third countries;

- Restructuring and conversion of vine plantations;

- Financial support for green harvest;

- New measures to manage crises - crop insurance and setting up mutual funds.

The state of viticulture in Bulgaria gives rise to outline the following prospects:

- Adjustment of production structure to the requirements of the international market;

- Introduction of varieties with different ripening period to overcome the seasonality and expanding production on large fruit seedless and seed varieties for consumption in fresh condition and juices from table varieties.

- Increasing acreage, mostly with quality red and white grape varieties and production of quality 
wines with pronounced environmental with assertive individuality.

- Using of certified branch planting material;

- Lighter and cheaper supporting structures and replacing them with simpler forms of cultivation;

- Improving production technologies, through maximum mechanization on technological processes;

- Creation of vine arrays with a greater number of vines per unit area (4000-5000 vines/ ha);

- Correctly territorial location, specialization and concentration on vine arrays depending on the biological requirements of varieties to soil and climatic conditions of the region;

- Investments for increasing the quality of human potential through applying the systems of education and qualification.

\section{References}

[1] http://www. thecityedition.com/2012/GPS. html

[2] National Strategy for Development of viticulture and winemaking in the Republic of Bulgaria 2005- 2025

[3] National Vine and Wine Chamber

[4] MAF, department "Agrostatistics", "Production of grapes and wine" - newsletters from (2000) to (2016)

[5] D. Pantaleeva. "Condition, opportunities and prospects for development of viticulture in Bulgaria", Econ. Mgmt of Agriculture, J. E. 5, 14-22 (2010)

[6] D. Toteva., P. Kirovski. Impact of the Common Agricultural Policy on the competitiveness, opportunities and prospects for development on the vinous viticulture in Bulgaria, Econ. Mgmt of Agriculture, J. E. 3-4, 33-40 (2011) 